\title{
研究論文
}

\section{Inorganic Extraction Studies on the System Alkylamine-nitric Acid}

\author{
Amberlite LA-1 and tri-iso-octylamine \\ アルキルアミンー硝酸系に扣ける諸元素の行動 \\ アンバーライトLA-1 およびトリインオクチルアミン \\ By Tomitaro ISHIMORI*, Kan KIMURA*, \\ Eiko NAKAMURA*, Kuniko TSUKUECHI* and Tomiko OSAKABE*
}

\begin{abstract}
The solvent extraction behavior of about sixty chemical elements was extensively surveyed in the alkylamine-nitric acid system, clarifying radiochemically the acid dependence of distribution ratios. The organic phases used were $10 \%(\mathrm{~V} / \mathrm{V})$ Amberlite LA-1 and $5 \%(\mathrm{~V} / \mathrm{V})$ tri-iso-octylamine xylene solution.

The highly extractable chemical species were not so many in number through two extraction systems. In most cases the acid dependence curves of a given element were not only similar each other between the two systems, but also resembled to that in $100 \%$ TBP- $-\mathrm{HNO}_{3}$ system. The exceptional high $\mathrm{K}_{d}$ value of technetium at $1 \mathrm{NHNO}_{3}$ suggested an application to separating ${ }^{99 \mathrm{~m} T \mathrm{C}}$ from neutron irradiated ammonium molybdate.
\end{abstract}

The alkylamines as the soivent extraction agent had been widely studied by many investigators from various point of view and in fact a few hundreds papers had been published before. However, these published results were given each in their own way.

So the extraction behavior of about sixty chemical elements, ranging from sodium to uranium, in Amberlite LA-1 (10\% xylene solution)-and tri-iso-octylamine (5\% xylene solution)-nitric acid system was comprehensively surveyed following solvent extraction study on the same alkylamines-hydrochloric acid system reported in the previous paper ${ }^{(1)}$.

\section{Experimental}

\section{Reagents}

Tri-iso-octylamine received from the Union Carbide and Chemicals Corp., N. Y., and
Amberlite LA-1, high molecular weight secondary amine, were used as $5 \%$ and $10 \%$ $(V / V)$ xylene solution without further purification respectively.

Nitric acid solutions were prepared by diluting commercial concentrated nitric acid, analytical grade. The acidity was adjusted to desired concentrations with aids of volumetric analysis.

\section{Radioisotopes used}

Table 1 includes a list of the radioisotopes used together with their target materials and purification methods whenever necessary. The imported radioisotopes were received from the ORNL, USA, or the Radiochemical Centre, Amersham, UK. Irradiation of targets and subsequent chemical treatments,

* 石森富太郎, 木村幹, 中村永子, 卓地邦子, 小呫部 富子。Japan Atomic Energy Res. Inst.(日本原子 力研究所) 
method of checking radiochemical purity, specific activities of tracers, and special cautions for measurement of radioactivities for ${ }^{212} \mathrm{~Pb},{ }^{95} \mathrm{Zr}-\mathrm{Nb},{ }^{210} \mathrm{Bi},{ }^{99} \mathrm{Mo}$ and ${ }^{113} \mathrm{Sn}$ were the same as the previous work ${ }^{(2)}$.

The radioactivities of ${ }^{88} \mathrm{Y},{ }^{231} \mathrm{Th}$ and ${ }^{287} \mathrm{U}$ were obtained as products of $(\gamma, n)$ reaction caused by $\boldsymbol{\gamma}$-rays from the linear accelarator of JAERI.

All of tracers were converted to nitrate before use. The definite oxidation states of Table 1 Radioactive tracers used

\begin{tabular}{|c|c|}
\hline Tracer & $\begin{array}{l}\text { Target (irradiated in) and chemical } \\
\text { treatment }\end{array}$ \\
\hline${ }^{24} \mathrm{Na}$ & $\mathrm{Na}_{2} \mathrm{CO}_{3}(\mathrm{JRR}-1)^{\dagger}$ \\
\hline${ }^{27} \mathrm{Mg}$ & Mg-metal(JRR-1) \\
\hline${ }^{28} \mathrm{Al}$ & Al-metal(JRR-1) \\
\hline${ }^{32} \mathrm{P}$ & $\begin{array}{l}\text { JAERI, interim facilities for radio- } \\
\text { isotope production }\end{array}$ \\
\hline${ }^{35} \mathrm{~S}$ & $\begin{array}{l}\text { JAERI, interim facilities for radio- } \\
\text { isotope production }\end{array}$ \\
\hline${ }^{38} \mathrm{Cl}$ & $\mathrm{NH}_{4} \mathrm{Cl}(\mathrm{JRR}-1)$ \\
\hline${ }^{42} \mathrm{~K}$ & $\mathrm{KNO}_{8}(\mathrm{JRR}-1)$ \\
\hline${ }^{15} \mathrm{Ca}$ & imported \\
\hline${ }^{40} \mathrm{Sc}$ & $\mathrm{Sc}_{2} \mathrm{O}_{3}(\mathrm{JRR}-2) \dagger$ \\
\hline${ }^{31} \mathrm{Ti}$ & Ti hydroxide(JRR-1) \\
\hline${ }^{52} \mathrm{~V}$ & $\mathrm{NH}_{4} \mathrm{VO}_{3}(\mathrm{JRR}-1)$ \\
\hline${ }^{51} \mathrm{Cr}$ & $\begin{array}{l}\text { JAERI, interim facilities for radio- } \\
\text { isotope production }\end{array}$ \\
\hline${ }^{56} \mathrm{Mn}$ & $\mathrm{MnO}_{2}(\mathrm{JRR}-1)$ \\
\hline${ }^{55,58} \mathrm{Fe}$ & imported \\
\hline${ }^{80} \mathrm{Co}$ & imported \\
\hline${ }^{05} \mathrm{Ni}$ & Ni sponge(JRR-1), separated from Co. \\
\hline${ }^{64} \mathrm{Cu}$ & Cu metal (JRR-1) \\
\hline${ }^{85} \mathrm{Zn}$ & imported \\
\hline${ }^{72} \mathrm{Ga}$ & $\mathrm{Ga}_{2} \mathrm{O}_{3}(\mathrm{JRR}-1)$ \\
\hline${ }^{71} \mathrm{Ge}$ & $\mathrm{GeO}_{2}(\mathrm{JRR}-2)$ \\
\hline${ }^{76} \mathrm{As}$ & $\mathrm{As}_{2} \mathrm{O}_{3}($ JRR-1) \\
\hline${ }^{75} \mathrm{Se}$ & imported \\
\hline${ }^{80,80 \mathrm{~m}} \mathrm{Br}$ & $\mathrm{NH}_{4} \mathrm{Br}(\mathrm{JRR}-1)$ \\
\hline${ }^{86} \mathrm{Rb}$ & imported \\
\hline${ }^{90} \mathrm{Sr}$ & milked from ${ }^{90} \mathrm{Sr}$ \\
\hline${ }^{85} \mathrm{Sr}$ & imported \\
\hline${ }^{81} \mathrm{Y}$ & imported \\
\hline${ }^{88} \mathrm{Y}$ & $\mathrm{Y}_{2} \mathrm{O}_{3}$ (LINIAC) \\
\hline${ }^{95} \mathrm{Zr}$ & imported \\
\hline${ }^{93} \mathrm{Nb}$ & imported \\
\hline${ }^{99} \mathrm{Mo}$ & ammonium molybdate (JRR-1) \\
\hline${ }^{99} \mathrm{Tc}$ & imported \\
\hline${ }^{106} \mathrm{Ru}$ & imported \\
\hline${ }^{109} \mathrm{Pd}$ & Pd metal (JRR-1), purified from ${ }^{111} \mathrm{Ag}$ \\
\hline${ }^{110 m} \mathrm{Ag}$ & $\mathrm{AgNO}_{3}(\mathrm{JRR}-1)$ \\
\hline${ }^{115 m} \mathrm{Cd}$ & imported \\
\hline${ }^{114 m}$ In & imported \\
\hline${ }^{113} \mathrm{Sn}$ & imported \\
\hline${ }^{124} \mathrm{Sb}$ & imported \\
\hline
\end{tabular}

\begin{tabular}{|c|c|}
\hline Tracer & $\begin{array}{l}\text { Target (irradiated in) and chemical } \\
\text { treatment }\end{array}$ \\
\hline${ }^{127,129} \mathrm{Te}$ & $\mathrm{TeO}_{2}(\mathrm{JRR}-2)$ \\
\hline${ }^{181} I$ & $\begin{array}{l}\text { JAERI, interim facilities for radio- } \\
\text { isotope production }\end{array}$ \\
\hline${ }^{187} \mathrm{Cs}$ & imported \\
\hline${ }^{189} \mathrm{Ba}$ & $\mathrm{Ba}(\mathrm{OH})_{2} 2 \mathrm{H}_{2} \mathrm{O}(\mathrm{JRR}-1)$ \\
\hline${ }^{140} \mathrm{La}$ & $\mathrm{La}_{2} \mathrm{O}_{8}$ (JRR-1) \\
\hline${ }^{M 4} \mathrm{Ce}$ & imported \\
\hline${ }^{147 P m}$ & imported \\
\hline${ }^{152,154} \mathrm{Eu}$ & imported \\
\hline${ }^{100} \mathrm{~Tb}$ & $\mathrm{~Tb}_{4} \mathrm{O}_{7}(\mathrm{JRR}-2)$ \\
\hline${ }^{177} \mathrm{Lu}$ & $\mathrm{Lu}_{2} \mathrm{O}_{3}(\mathrm{JRR}-1,2)$ \\
\hline${ }^{181} \mathrm{Hf}$ & imported \\
\hline${ }^{282} \mathrm{Ta}$ & imported \\
\hline${ }^{185} \mathrm{~W}$ & imported \\
\hline${ }^{186,188} \mathrm{Re}$ & $\operatorname{Re}$ metal(JRR-1) \\
\hline${ }^{101} \mathrm{Os}$ & imported \\
\hline${ }^{104} \mathrm{Ir}$ & Ir sponge (JRR-1) \\
\hline${ }^{199} \mathrm{Pt}$ & Pt sponge(JRR-1), separated from Au \\
\hline${ }^{198} \mathrm{Au}$ & Au metal(JRR-1) \\
\hline${ }^{208} \mathrm{Hg}$ & imported \\
\hline${ }^{204} \mathrm{Tl}$ & imported \\
\hline${ }^{212} \mathrm{~Pb}$ & redioactive deposit of Th \\
\hline${ }^{210} \mathrm{Bi}$ & milked from RaDEF by TBP extraction \\
\hline${ }^{231} \mathrm{Th}$ & $\underset{\text { extraction }^{(3)}}{\mathrm{ThO}_{2} \text { (LINIAC), separated by } \mathrm{TBP}}$ \\
\hline${ }^{233} \mathrm{~Pa}$ & $\begin{array}{l}\mathrm{Th}\left(\mathrm{NO}_{3}\right)_{4}(\mathrm{JRR}-1) \text {, separated by TBP } \\
\text { extraction }\end{array}$ \\
\hline${ }^{237} \mathrm{U}$ & $\underset{\text { extraction }^{(5)}}{\mathrm{UO}_{2} \text { (LINIAC), separated by } \mathrm{TBP}}$ \\
\hline${ }^{239} \mathrm{~Np}$ & $\begin{array}{l}\mathrm{UO}_{2}\left(\mathrm{NO}_{3}\right)_{2} 6 \mathrm{H}_{2} \mathrm{O}(\mathrm{JRR}-1) \text {, separated by } \\
\text { TBP extraction }\end{array}$ \\
\hline
\end{tabular}

Table 2 Chemical treatment of tracers

\begin{tabular}{|c|c|}
\hline Element & Treatment \\
\hline \multirow[t]{2}{*}{${ }^{3+} \mathrm{As}$} & reduced with ascorbic acid \\
\hline & $\begin{array}{l}\text { The aqueous solution was scrubbed with } \\
\text { the organic solution. }\end{array}$ \\
\hline${ }^{\mathrm{s}+}$ As & oxydized with $\mathrm{KClO}_{4}$ in $6 \mathrm{~N} \mathrm{HCl}$ \\
\hline${ }^{4+} \mathrm{Se}$ & heated in $4 \mathrm{~N} \mathrm{HCl}$ with ascorbic acid \\
\hline${ }^{3+} \mathrm{Ce}$ & reduced with $\mathrm{NH}_{2} \mathrm{OHHCl}$ \\
\hline \multirow[t]{2}{*}{${ }^{4+} \mathrm{Ce}$} & oxydized with ceric ammonium nitrate \\
\hline & $\begin{array}{l}\text { The organic solution was scrubbed } 3 \\
\text { times. }\end{array}$ \\
\hline${ }^{2+} \mathrm{Hg}$ & heated in conc. $\mathrm{HNO}_{3}$ \\
\hline${ }^{1+} \mathrm{Tl}$ & reduced with $\mathrm{NH}_{2} \mathrm{OH} \cdot \mathrm{HCl}$ \\
\hline${ }^{\mathrm{s}+\mathrm{T} l}$ & oxydized with ceric ammonium nitrate \\
\hline \multirow[t]{2}{*}{${ }^{4+} \mathrm{Np}_{\mathrm{p}}$} & reduced with ferrous sulfamate \\
\hline & $\begin{array}{l}\text { The organic layer was scrubbed } 4 \text { times } \\
\text { with the fresh aqueous solution. }\end{array}$ \\
\hline${ }^{5+} \mathrm{Np}$ & $\begin{array}{l}{ }^{4+} \mathrm{Np} \text { and }{ }^{6+} \mathrm{Np}_{\mathrm{p}} \text { was removed after } \\
\text { heating in } \mathrm{IN} \mathrm{HClO} \text {, solution. }\end{array}$ \\
\hline${ }^{\mathrm{a}} \mathrm{Np}$ & $\begin{array}{l}\text { oxydized with ceric ammonium nitrate } \\
\text { The scrubbing was the same above. }\end{array}$ \\
\hline
\end{tabular}


Vol. 5, No. 2 (1963)
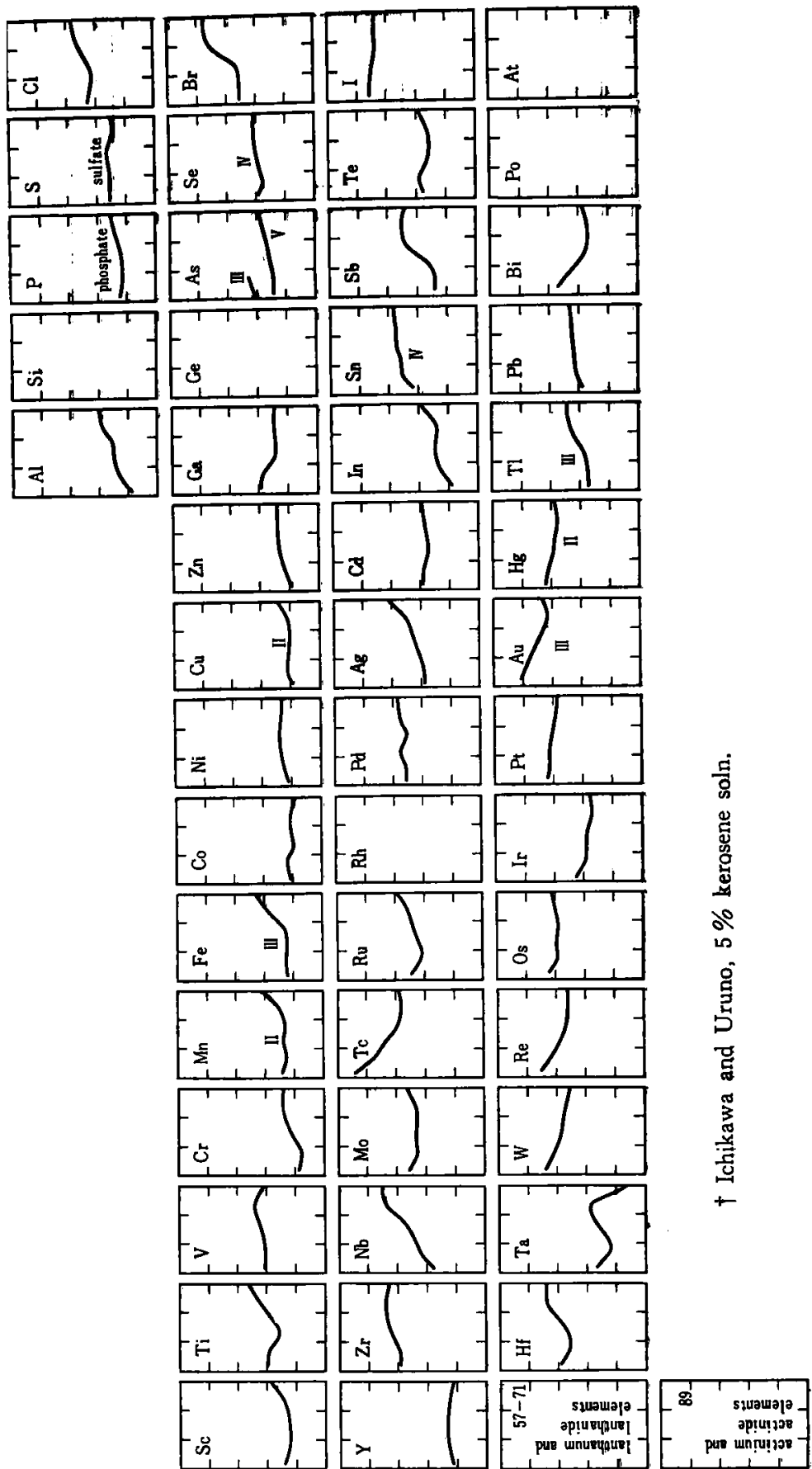

E.T.
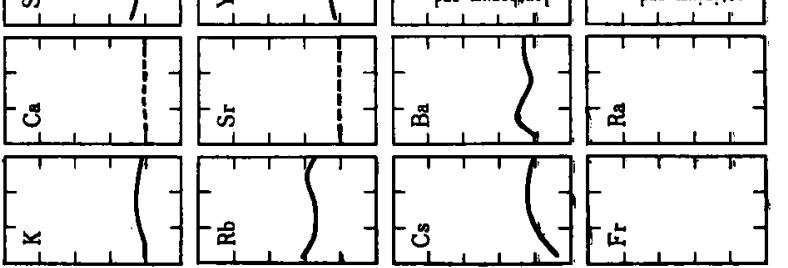

$=7$

"o응 is
-

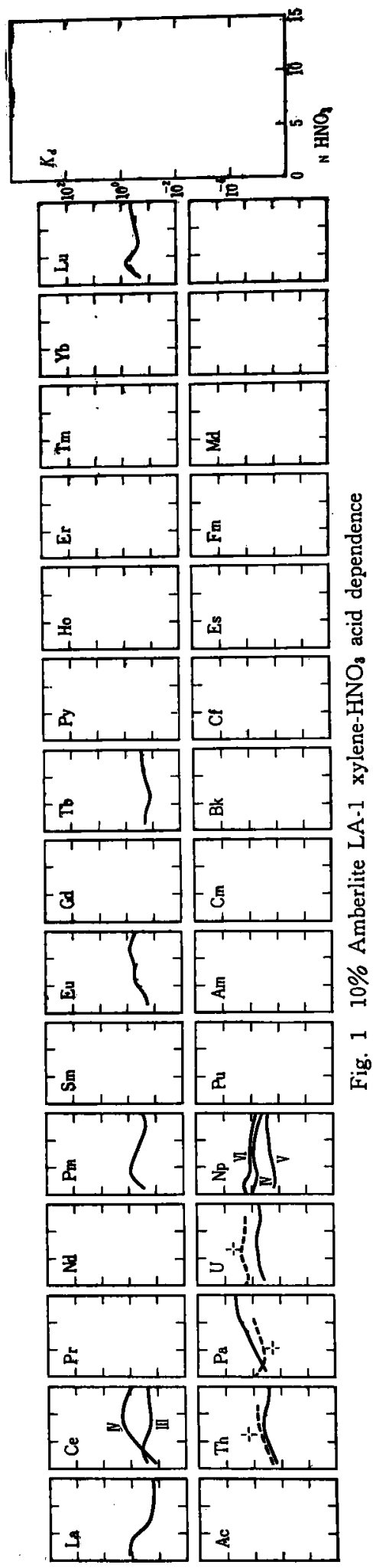



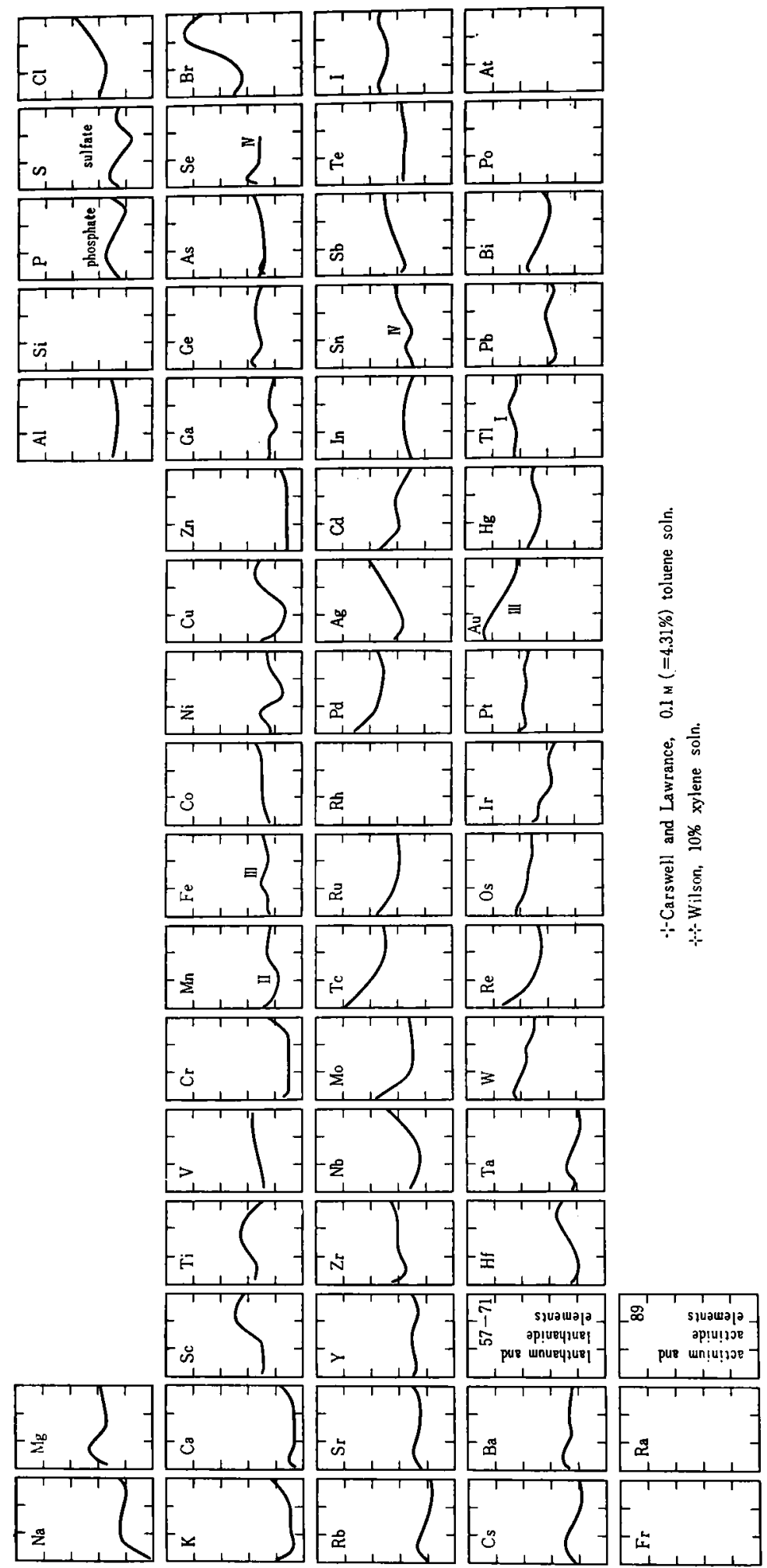
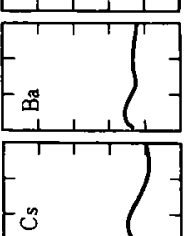
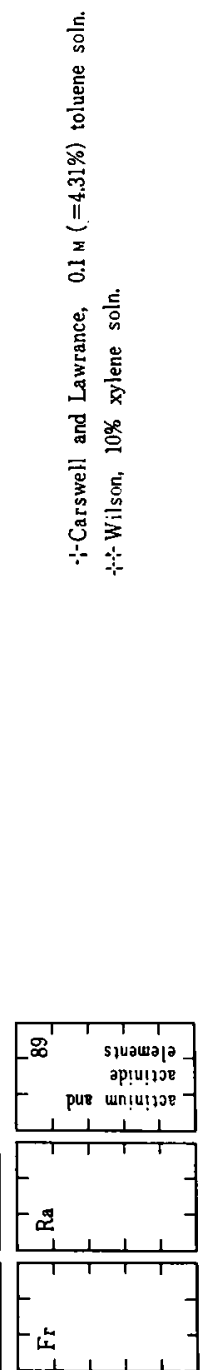
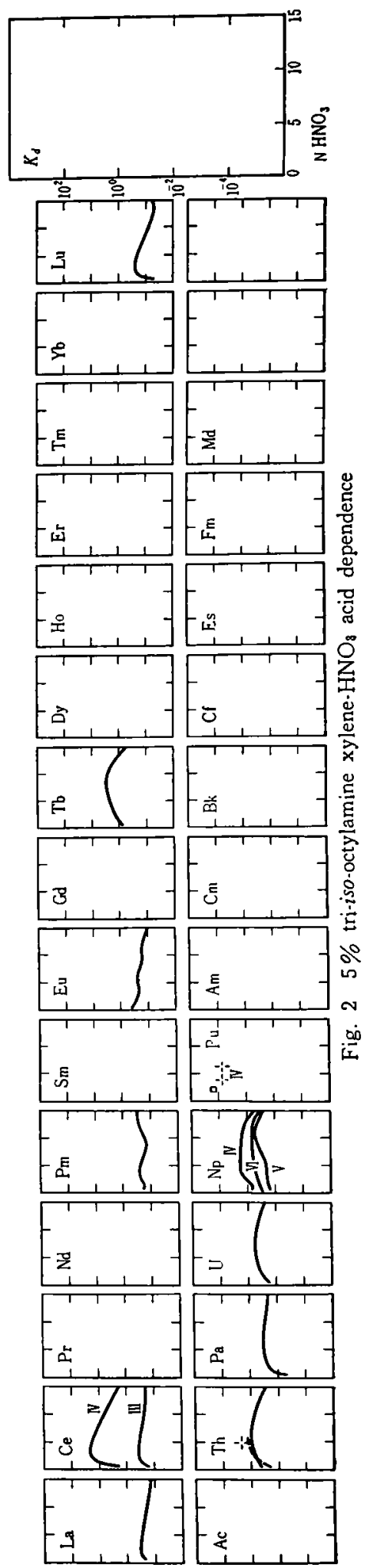


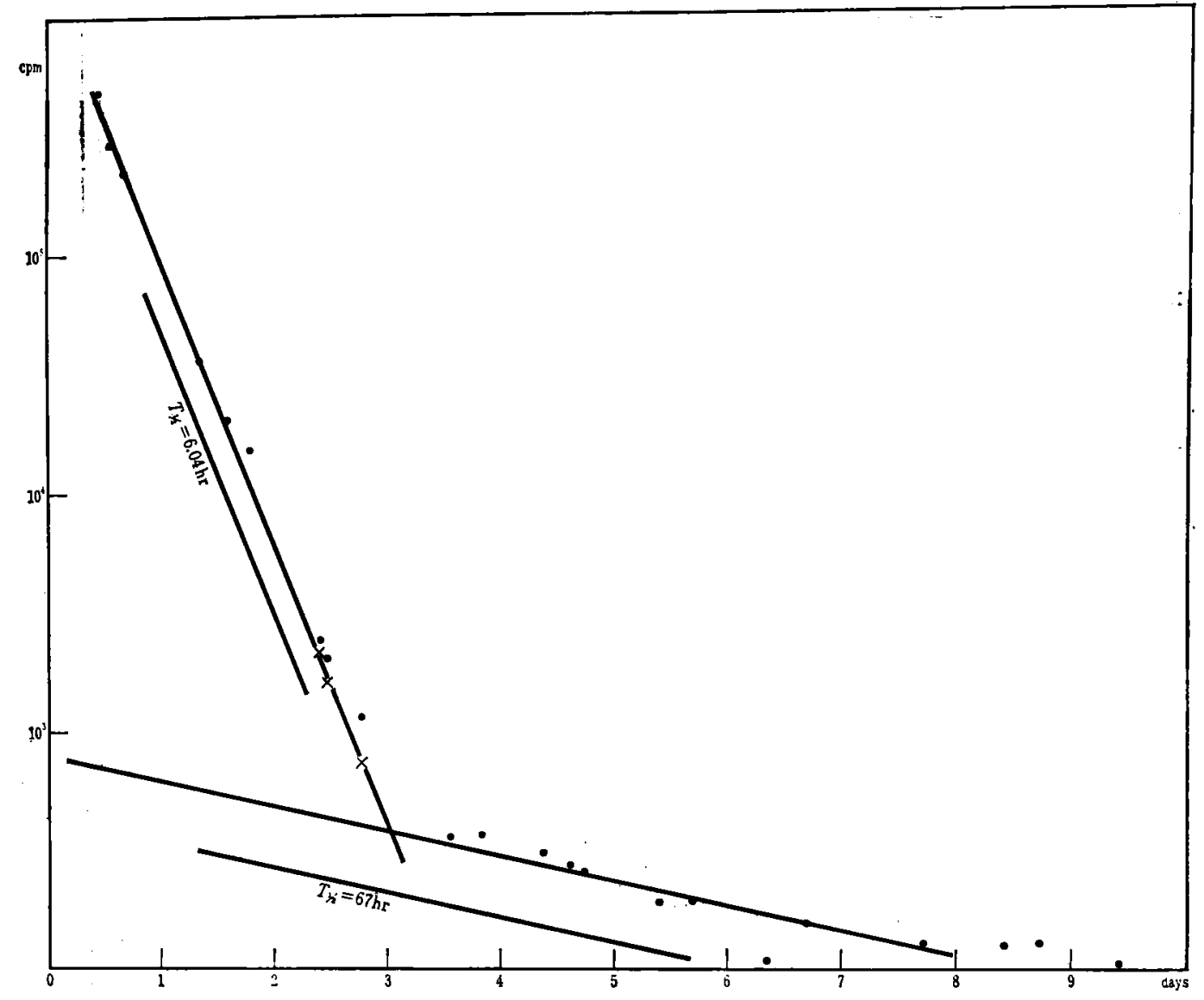

Fig. 3 Decay curve of ${ }^{99 m} \mathrm{Tc}$

some tracers were attained by the suitable chemical treatment appearing in Table 2.

\section{Determination of distribution ratios}

Distribution ratios were determined radiometrically as was stated in the previous paper $^{(1)}$. In the present work, the organic phase was pre-equilibrated with the corresponding nitric acid.

\section{Results and Discussion}

The results obtained are summarized in Figs. 1 and 2 as a series of graphs of log. $K_{a}$ vs. normality of nitric acid, where $K_{d}$ is the ditsribution ratio. Because of insufficient amount of radioactivities obtained or too low $K_{d}$ value, some distribution ratios could not be determined very accurately.

It is seen in Figs. 1 and 2 that $K_{d}$ values are generally low in the surveyed solvent

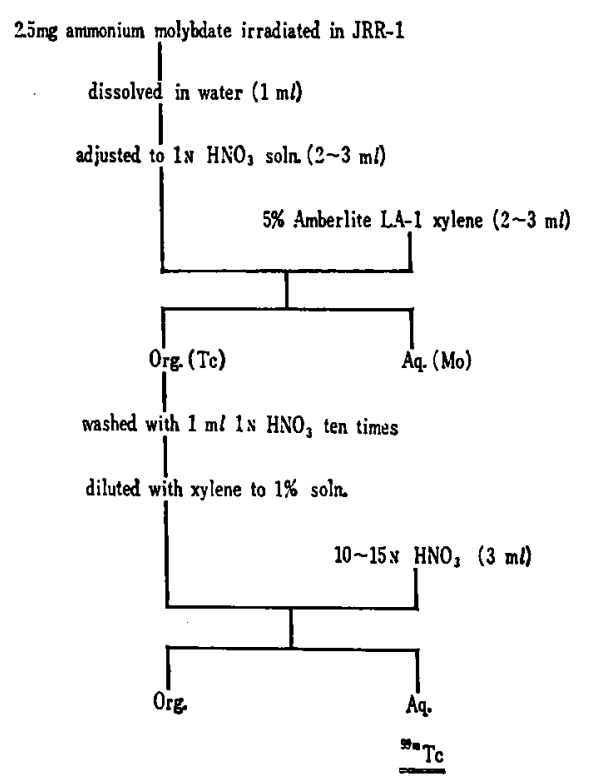

Fig. 4 Preparation of ${ }^{99 m} \mathrm{Tc}$ 


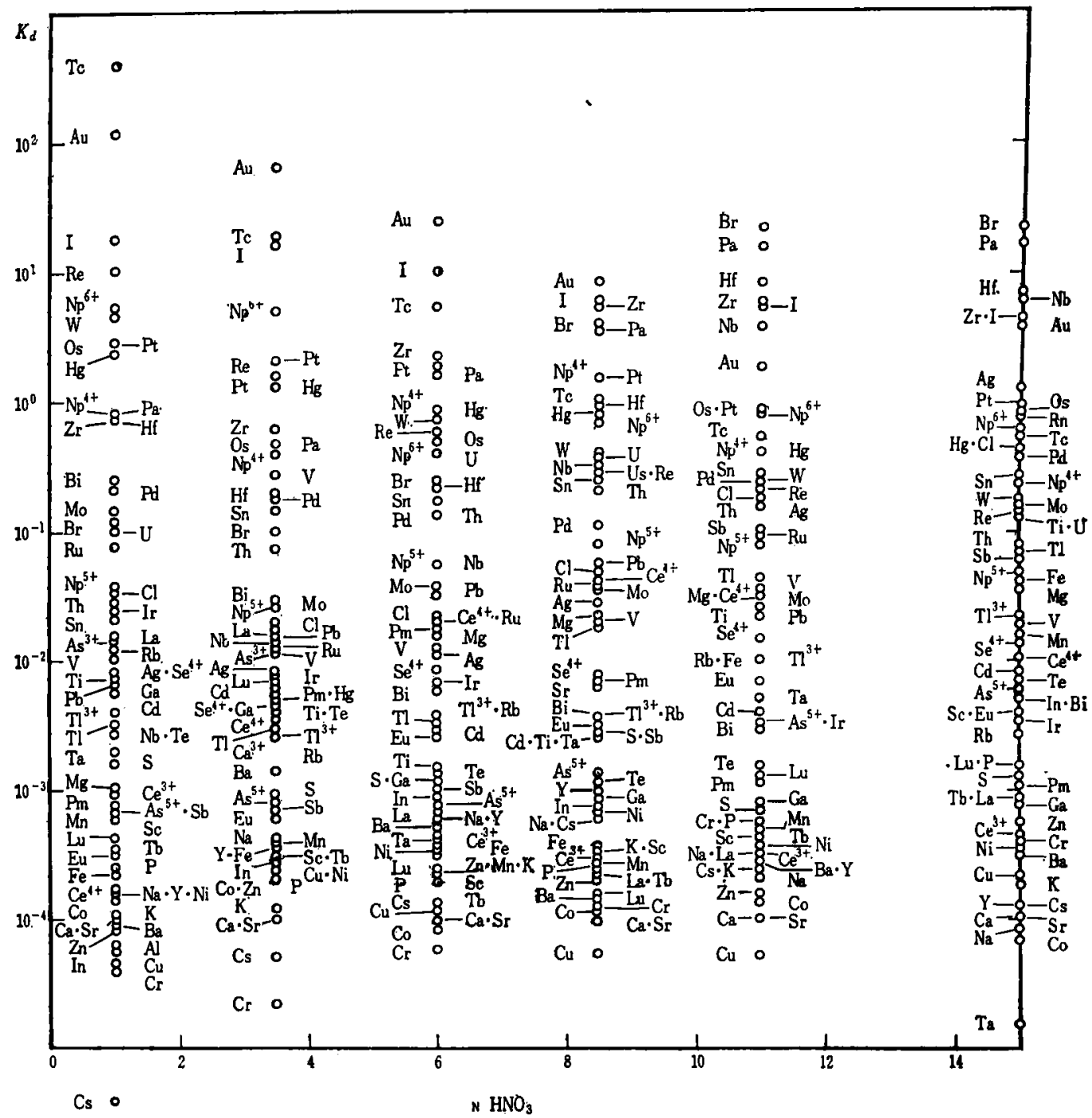

Fig. $5 K_{a}$ values in $10 \% \mathrm{LA}-1-\mathrm{HNO}_{3}$ system

extraction systems. The extractable species with $5 \%$ TIOA* $^{*}$ xylene solution are bromine, iodine, gold, thallium, and neptunium $(\eta)$; technetium, paradium, rhenium and cerium (II) in low acidity region. On the other hand, 10\% Amberlite LA-1 xylene solution extracts bromine, iodine, zirconium, niobium, technetium, hafnium, tungsten, rhenium, gold and protactinium.

Generally speaking, acid dependence curves of a given element are very similar each other between the two extraction systems concerning $K_{a}$ values and the shape of curve. The distribution ratios for technetium, tungs- ten, rhenium, and bismuth decrease with increasing acidity, while those for chlorine, bromine, niobium and silver increase with increasing acidity in both solvent extraction systems.

The extraction curves of cerium $(\mathbb{N})$, thorium and uranium have peaks at about $7 \mathrm{~N}$ acid.

The distribution ratios for $\operatorname{arsenic}(\mathbb{I})$, zirconium, niobium, molybdenum, technetium, iodine, $\operatorname{tin}(\mathbb{N})$, hafnium and protactinium in Amberlite LA-1 system are remarkably higher than those in TIOA system. Contrary to 


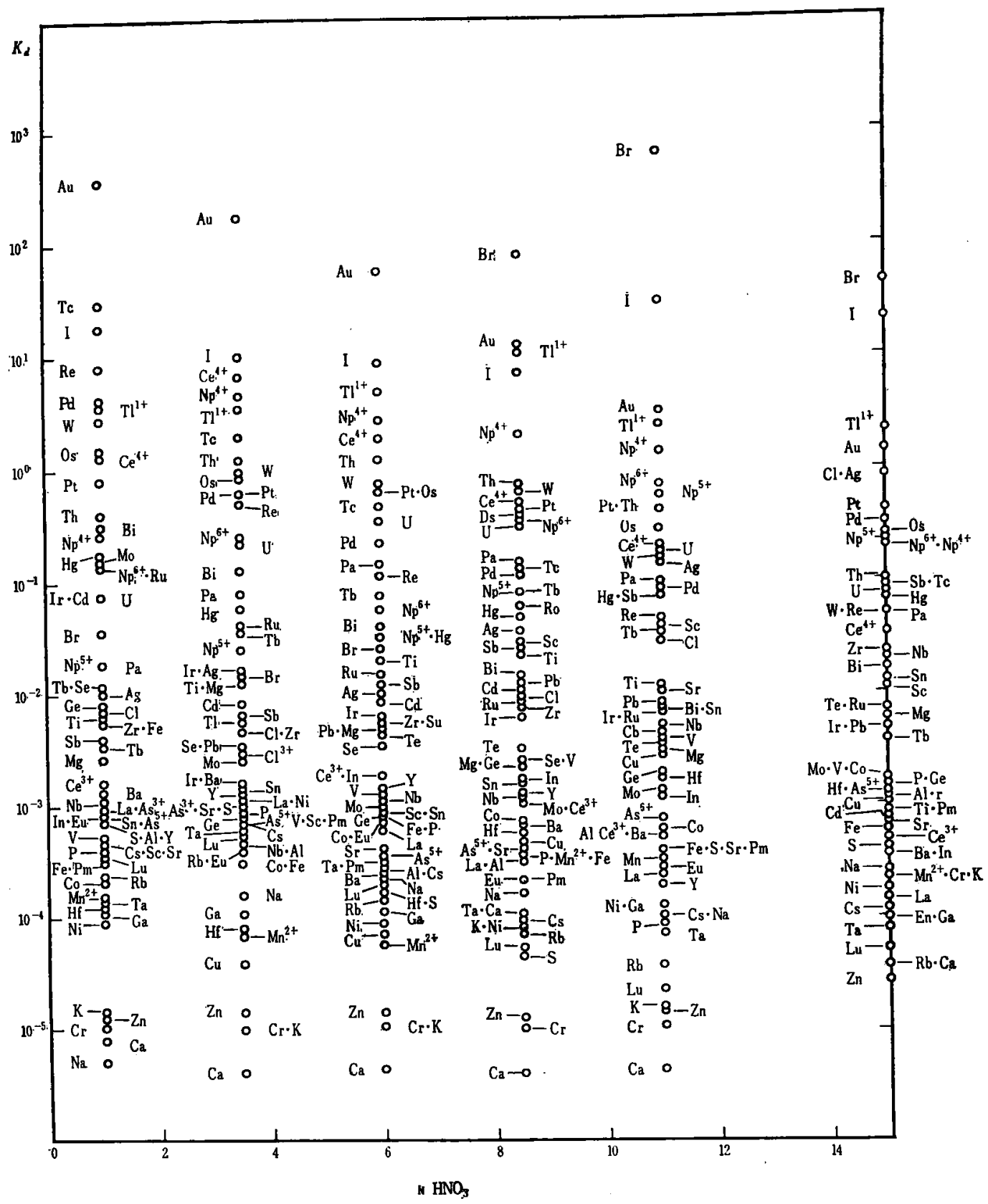

Fig, $6 K_{d}$ values in $5 \%$ TIOA-HNO 3 system

these elements, cerium $(\mathbb{V})$ and thorium are more extractable in $\mathrm{TIOA}-\mathrm{HNO}_{3}$ system than Amberlite LA-1.

Most acid dependence curves of a given element in the present extraction systems are very close to that in $100 \% \mathrm{TBP}-\mathrm{HNO}_{3}$ system $^{(n)}$. Especially the similarity between $10 \%$ Amberlite LA-1 and $100 \%$ TBP-HNO systems is proved except for scandium, yttrium, lanthanum and lanthanide elements which indicate higher $K_{d}$ values in the TBP extraction system.

Figs. 1 and 2 also contain other investigators' results for thorium ${ }^{(8)(9)}$, protactinium ${ }^{(8)}$, uranium $^{(8)}$ and plutonium ${ }^{00}$. Although slight differences are found between these known 
acid dependence curves and the present, tnis could be attributed to the different conditions in the organic diluent or in the concentration of alkylamines chosen.

Technetium- $-99 \mathrm{~m}$ is available as a radioactive tracer after isolating from neutron irradiated molybdenum compound. Figs. 1 and 2 give an isolation method basing on fairly high $K_{d}$ values of technetium and low values of molybdenum at $1 \mathrm{~N} \mathrm{HNO}_{3}$ in the amine extraction. Starting from $2.5 \mathrm{mg}$ ammonium molybdate irradiated in JRR-1 for $5 \mathrm{hr}$ and cooled for 6 days, about $1 \mathrm{mc}$ of technetium-99m was extracted with $5 \%$ Amberlite LA-1 xylene solution from $1 \mathrm{~N} \mathrm{HNO}_{3}$. The radiochemical purity was shown to be $99.8 \%$ from the decay curve measurement (Fig. 3). The separation process used is represented in Fig. 4.

Figs. 5 and 6 give the exact $K_{a}$ values for each element. These figures serve an advantage to see easily the difference of $K_{d}$ values of tow elements.
(Received August 2, 1962)

\section{-REFERENCE- -}

(1) T. ISHIMORI, H. M. SAMmoUR, K. KIMURA, H. MURAKami, T. IZUMI: This Journal, 3, No. 9, 698 (1961).

(2) T. Ishimori, E. Nakamura, H. MURAKami: ibid., 3, No. 8, 590 (1961).

(3) E. NAKAMURA: to be published.

(4) T. ISHIMORI, K. KIMURA, E. NAKAMURA, et al.: 4th Japan Conf. on Radioisotope, (1961).

(5) T.ISHIMORI, T. KUROY ANAGI, E. NAKAMURA: to be published.

(6) T. Ishimori, E. Nakamura: Bull. Chem. Soc. Japan, 32, 713 (1959).

(7) T. Ishimori, K. WATANABE: ibid., 33, 1443 (1960).

(8) F. IchiKawa, S. URUNo: ibid., 33, 569 (1960).

(9) D. J. Carswell, J. J. Lawrance: J. Inorg. Nucl. Chem., 11, 69 (1959).

(10) A. S. Wilson: Proc. 2nd United Nations Intern. Conf. Peaceful Uses Atomic Energy, 17, $\mathrm{P} / 544,348$ (1958).

\title{
研究論文
}

\section{A Study of Plutonium Recycle in a Gas-cooled, Graphite-moderated Reactor, (II)}

\author{
黒鉛减速ガス冷却炉におけるプルトニウムリサィクルの研究，（II）
}

\section{By Kunihiko UEMATSU*}

The modified bidirectional fuel management method on plutonium recycle in a gas-cooled and graphite-moderated reactor was investigated. The modified bidirectional fuel management was so designed that the fresher fuel and the more burned fuel existed at the outer and inner regions of the reactor, respectively, to reduce the peak to average ratio of power density.

This fueling method was effective to reduce the peak to average ratio of power density without sacrificing much burn-up of the fuel. The optimum irradiation control factors, $A$ 's, were at around 0.5 and 0.3 for natural uranium feed and $1.0^{\mathrm{a}} \mathrm{s}$ enriched uranium feed, respectively.

* 植松邦彦。Dept. Nucl. Engng., Kyoto Univ. (京都大学工学部原子核工学教室) 